\title{
A Decrease in GTP Content is Associated with Aerial Mycelium Formation in Streptomyces MA406-A-1
}

\author{
By $\mathrm{KOZO}$ OCH I \\ Exploratory Research Laboratories, Fujisawa Pharmaceutical Co. Ltd, 2-1-6 Kashima, \\ Yodogawa-ku, Osaka 532, Japan
}

(Received 24 April 1985; revised 26 August 1985)

Aerial mycelium formation by Streptomyces sp. MA406-A-1, a formycin-producing strain, was suppressed by the presence of excess nutrient. In such suppressed cultures, decoyinine, which specifically inhibits GMP synthetase, initiated the formation of aerial mycelium at concentrations which only partially inhibited growth. The intracellular GTP pool of organisms growing in liquid culture markedly decreased on the addition of decoyinine. Decoyinine was also effective in initiating aerial mycelium formation of three other Streptomyces spp. examined. Regardless of the successful initiation of aerial mycelium formation, the ability of the cells to produce antibiotics (formycin or actinomycin D) did not increase, but decreased, on the addition of decoyinine. It is concluded that aerial mycelium formation by Streptomyces results from a decrease in the pool of GTP (or GDP), whereas antibiotic synthesis results from a different signal(s).

\section{INTRODUCTION}

Members of the genus Streptomyces develop aerial mycelium from substrate mycelium when cultured on a suitable solid medium. This morphological differentiation is usually suppressed by the presence of an excess of nitrogen or a readily utilizable carbon source such as glucose (Kalakoutskii \& Agre, 1976; Redshaw e't al., 1976). Streptomyces spp. also produce numerous antibiotics; this production is usually coupled to morphological differentiation (Chater, 1984; Chater \& Hopwood, 1984). In Bacillus subtilis, the decrease of intracellular GTP (or GDP) content caused by the stringent response or more directly by inhibitors of GMP synthesis, results in an initiation of sporulation (Lopez et al., 1979; Freese, 1981 ; Ochi et al., 1981 ; Ochi \& Freese, 1983). Freese et al. (1984) also stressed the importance of decrease of GTP for the initiation of differentiation (ascospore formation) in Saccharomyces cerevisiae. I have shown that in B. subtilis sporulation results from a decrease of GTP (e.g. caused by the stringent response), whereas antibiotic synthesis results from a different effect of the stringent response (Ochi \& Ohsawa, 1984; Ochi, 1985). Here I report that a decrease of GTP also initiates aerial mycelium formation (but not antibiotic formation) by a Streptomyces sp.

\section{METHODS}

Bacterial strains. Streptomyces sp. MA406-A-1, a wild-type, prototrophic formycin-producing strain, was provided by the Institute of Microbial Chemistry, Tokyo, Japan. Other Streptomyces spp. used were S. griseus NRRL 3851, S. lividans JII 1326, and S partulus ATCC 12434. These strains were stored at 4 C after growing on sporulation medium (see below) at $30^{\circ} \mathrm{C}$ for $10 \mathrm{~d}$

Media and culture conditions. Sporulation medium $(10 \mathrm{ml}$ per $5.3 \mathrm{~cm}$ diameter plate $)$ consisted of $2 \%(\mathrm{w} / \mathrm{v})$ soluble starch, $0.4 \%(\mathrm{w} / \mathrm{v})$ yeast extract and $2 \%(\mathrm{w} / \mathrm{v})$ agar (adjusted to $\mathrm{pH} 7.0$ with $\mathrm{NaOH}$ ). Synthetic liquid medium for formycin production consisted of $(\mathrm{w} / \mathrm{v}): 1 \%$ glucose, $0.2 \%$ lysine. $\mathrm{HCl}, 0.2 \%$ glutamine, $0.2 \%$ ammonium sulphate, $0.5 \% \mathrm{NaCl}, 0.05 \% \mathrm{KCl}, 0.05 \% \mathrm{MgSO}_{+} .7 \mathrm{H}_{2} \mathrm{O}, 0.001 \% \mathrm{ZnSO}_{4} .7 \mathrm{H}_{2} \mathrm{O}$, and $100 \mathrm{~mm}$-phosphate buffer (pH 7.0). It was adjusted to $\mathrm{pH} 7.0$ with $\mathrm{NaOH}$, and sterilized by autoclaving at $120^{\circ} \mathrm{C}$ for $20 \mathrm{~min}$, apart from the glucose solution, which was autoclaved separately. 
Streptomyces sp. MA406-A-1 was precultured at $25^{\circ} \mathrm{C}$ for $24 \mathrm{~h}$ by inoculating a spore suspension into maltose/polypeptone/yeast extract medium $(50 \mathrm{ml}$ in a $250 \mathrm{ml}$ flask) (Ochi et al., 1974). Cells were harvested by centrifugation $(8000 \mathrm{~g}, 10 \mathrm{~min})$, washed twice with $50 \mathrm{ml}$ saline $(0.9 \% \mathrm{NaCl})$, and resuspended in the original volume of saline. Washed cells $(2 \mathrm{ml})$ were inoculated into $50 \mathrm{ml}$ synthetic medium in $250 \mathrm{ml}$ flasks and cultured at $30^{\circ} \mathrm{C}$ on a rotary shaker $(230$ r.p.m.). In some experiments (Figs $4 b$ and $5 b$ ), $1 \mathrm{ml}$ preculture broth was inoculated directly into fresh maltose/polypeptone/yeast extract medium $(50 \mathrm{ml}$ in $250 \mathrm{ml}$ flasks $)$, and cultured at $25^{\circ} \mathrm{C}$ on a rotary shaker (230 r.p.m.).

For production of actinomycin D by $S$. parculus ATCC 12434 this strain was grown on glutamic acid/histidine/fructose medium as described by Williams \& Katz (1977).

For study of aerial mycelium formation, spore: $\left(10^{8}-3 \times 10^{8}\right)$ of each Streptomyces strain were inoculated onto sporulation medium or sporulation medium supplemented with $1 \%(\mathrm{w} / \mathrm{v})$ polypeptone, and incubated at $30 \mathrm{C}$ for $7-10 \mathrm{~d}$.

Determination of nucleotide pools. The intracellular concentrations of nucleotides (including ppGpp and pppGpp) were assayed by HPLC, as described by Ochi et al. (1981), except that cells ( $50 \mathrm{ml})$ were collected quickly by filtration (no. 2 filter paper, diameter $9 \mathrm{~cm}$, Toyo Roshi Co.), and extracted with $10 \mathrm{ml} 1 \mathrm{M}$-formic acid.

Assay of formycin. Formycin was determined by bioassay with Xanthomonas oryzae IFO 3312 as the test organism, as follows. The strain was grown at $30{ }^{\circ} \mathrm{C}$ for $24 \mathrm{~h}$ in liquid medium consisting of $(\mathrm{w} / \mathrm{v}): 2 \%$ sucrose, $0.5 \%$ peptone, $0.2 \%$ yeast extract, $0.2 \%$ glutamate, $0.2 \% \mathrm{~K}_{2} \mathrm{HPO}_{4}, 0.1 \% \mathrm{MgCl}_{2} .6 \mathrm{H}_{2} \mathrm{O}$ and $0.01 \% \mathrm{FeSO}_{4} .7 \mathrm{H}_{2} \mathrm{O}$ (adjusted to $\mathrm{pH} 7.0$ with $\mathrm{NaOH}$ and autoclaved at $120^{\circ} \mathrm{C}$ for $20 \mathrm{~min}$ ). Then $1 \mathrm{ml}$ of the culture was suspended in $100 \mathrm{ml}$ of the same medium plus $0.9 \%(\mathrm{w} / \mathrm{v})$ agar which had been autoclaved and cooled to 42 "C. This suspension was immediately poured into plates $(10 \mathrm{ml}$ per $8.5 \mathrm{~cm}$ diameter plate). Paper discs of $8 \mathrm{~mm}$ diameter were soaked with $50 \mu \mathrm{l}$ samples of test solution or standard formycin solution, and placed on the test plates. The diameter of circular haloes around the filter discs was determined after $24-30 \mathrm{~h}$ incubation at $30^{\circ} \mathrm{C}$.

Assay of actinomycin D. Actinomycin D was assayed spectrophotometrically (Katz \& Weissbach, 1963) at $443 \mathrm{~nm}$ after extraction with ethyl acetate.

Reagents. Decoyinine (a specific inhibitor of GMP synthetase) was a gift from Dr J. E. Grady, The Upjohn Co., Kalamazoo, Michigan, USA. Yeast extract and polypeptone were purchased from Daigo Eiyo Kagaku and Wako Pure Chemical Industries, respectively. MOPS was from Nakarai Chemicals.

\section{RESULTS}

\section{Aerial mycelium formation under various culture conditions}

Streptomyces sp. MA406-A-1 grew well on sporulation medium and developed aerial mycelium $2 \mathrm{~d}$ after inoculation. However, aerial mycelium formation was almost completely suppressed during $10 \mathrm{~d}$ incubation wher the sporulation medium was supplemented with $1 \%$ $(\mathrm{w} / \mathrm{v})$ polypeptone, or when soluble starch was replaced by $1 \%(\mathrm{w} / \mathrm{v})$ glucose. The suppression of aerial mycelium formation by glucose was due to a decrease in $\mathrm{pH}$ (down to 4.6) of the medium because addition of $100 \mathrm{~mm}$-MOPS buffer to maintain the $\mathrm{pH}$ at 7.0 completely restored the ability to develop aerial mycelium $2 \mathrm{~d}$ after inoculation. In contrast, the repression by polypeptone was not due to change in $\mathrm{pH}$; the $\mathrm{pH}$ of the medium increased only slightly (up to 7.4) after $2 \mathrm{~d}$ incubation. Moreover, addition of MOPS buffer failed to restore the ability to develop aerial mycelium. Thus, the aerial mycelium formation of this strain seemed to be subject to nitrogen suppression.

When cultures grown in conditiors that would normally suppress aerial mycelium development were treated with decoyinine at concentrations which only partially inhibited growth, they were able to develop aerial mycelium after $2-3 \mathrm{~d}$ incubation. Fig. 1 shows the induction of zones of sporulation (shown by examination of sections through the agar to correspond to aerial mycelium formation) by decoyinine in the presence of $1 \%$ po eptone. A larger amount of decoyinine (i.e. with discs soaked with 10 or $20 \mathrm{~mm}$-decoyinin, markedly inhibited growth, and aerial mycelia were formed only around the zone (not shown). The ability of decoyinine to restore aerial mycelium development was lowered if the medium contained a high concentration $(3 \%)$ of polypeptone; with this medium the growth rate of substrate mycelium was also lowered. Addition of folic acid (0.1-0.5 mM), a metabolite of GTP, did not suppress the initiation of aerial mycelium formation caused by decoyinine addition. To determine the effective concentration of decoyinine for aerial mycelium formation, spores were inoculated on plates with fixed concentrations of decoyinine (Fig. 2). Pronounced aerial mycelium development was observed at $0.02-0 \cdot 1 \mathrm{~mm}$-decoyinine (maximal at $0.05 \mathrm{~mm}$ ); at these 


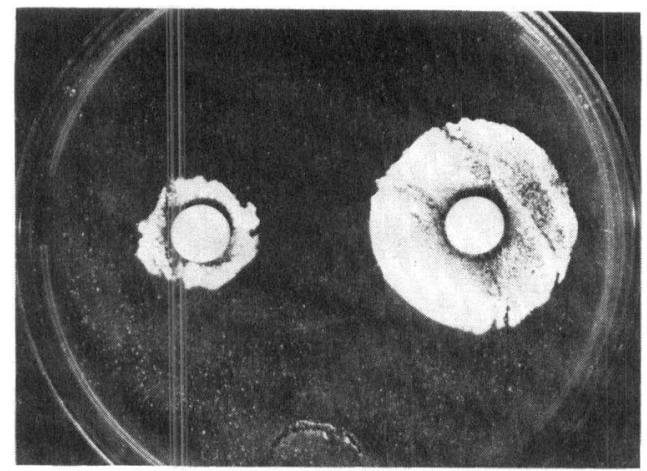

Fig. 1. Development of aerial mycelium (apparent as zones of sporulation) by Streptomyces sp. MA406A-1 on the addition of decoyinine. Spores were spread on sporulation agar supplemented with $1 \%$ polypeptone, and paper discs soaked with decoyinine solutions $(0.5 \mathrm{~mm}$, left; $3 \mathrm{~mm}$, right $)$ were put on the plate, which was then incubated at $30^{\circ} \mathrm{C}$ for $6 \mathrm{~d}$.

concentrations growth was only partially inhibited. Decoyinine concentrations higher than $0.5 \mathrm{~mm}$ caused severe growth inhibition, and aerial mycelium did not develop.

The effect of decoyinine on formycin production by Streptomyces sp. MA406-A-1 was studied (Fig. 3). Formycin production did not increase, but decreased, at all the decoyinine concentrations tested (even at $0.05 \mathrm{~mm}$, optimal for aerial mycelium formation).

To study whether decoyinine would initiate aerial mycelium formation of other Streptomyces strains, three species ( $S$. griseus, $S$. lividans and $S$. parvulus) were grown on sporulation medium supplemented with $1 \%$ polypeptone. On this medium no aerial mycelium developed even after $7 \mathrm{~d}$ incubation, but when discs soaked with suitable amounts of decoyinine (3-10 mM) were added aerial mycelium developed around the discs $1-2 \mathrm{~d}$ after inoculation (not shown).

\section{Effect of decoyinine on antibiotic production and nucleotide pools}

Formycin is produced in parallel with growth of Streptomyces sp. MA406-A-1 in synthetic medium (Ochi et al., 1979), but its production begins at the early stationary phase in complex medium (Ochi et al., 1974). Therefore the effect of decoyinine on the initiation of antibiotic production was studied in synthetic medium. Cells were grown in synthetic medium for $6 \mathrm{~h}$ (mid-exponential phase), harvested by filtration, and immediately resuspended in one-third of the original volume of fresh synthetic medium, giving a cell density of $1.2-1.4 \mathrm{mg}$ dry wt $\mathrm{ml}^{-1}$. The cell suspension was distributed into flasks containing various amounts of decoyinine, and incubated for $10 \mathrm{~h}$. Growth inhibition was slight at the lowest decoyinine concentrations tested, but it increased with increasing decoyinine concentration $(50 \%$ and $100 \%$ inhibition with $0.1 \mathrm{~mm}$ - and $0.4 \mathrm{~mm}$-decoyinine, respectively). Formycin production decreased at all but the lowest decoyinine concentrations tested (Fig. $4 a$ ).

One might suspect that since the physiology of the organism would be different in complex and synthetic medium, the lack of an effect of decoyinine on formycin production in synthetic medium might be an artefact resulting from the control of antibiotic production being uncoupled from the usual regulation. Therefore the effect of decoyinine on formycin production was also examined using complex (maltose/polypeptone/yeast extract) medium. Cells growing exponentially ( $6 \mathrm{~h}$ from inoculation) were harvested by filtration and suspended in one-third of the original volume of fresh complex medium, giving $2 \cdot 8-3 \cdot 2 \mathrm{mg}$ dry wt cells $\mathrm{ml}^{-1}$, followed by $18 \mathrm{~h}$ incubation with various amounts of decoyinine. As observed in synthetic medium, formycin-production decreased in the presence of decoyinine (Fig. $4 b$ ). In this case, $50 \%$ growth inhibition resulted with $0.2 \mathrm{~mm}$-decoyinine.

The changes in the intracellular nucleotide pool on the addition of decoyinine at concentrations which caused $50 \%$ growth inhibition $(0.1$ and $0.2 \mathrm{~mm}$ in synthetic and complex medium, respectively) were examined (Fig. 5). In synthetic medium, the pool size of GTP had 


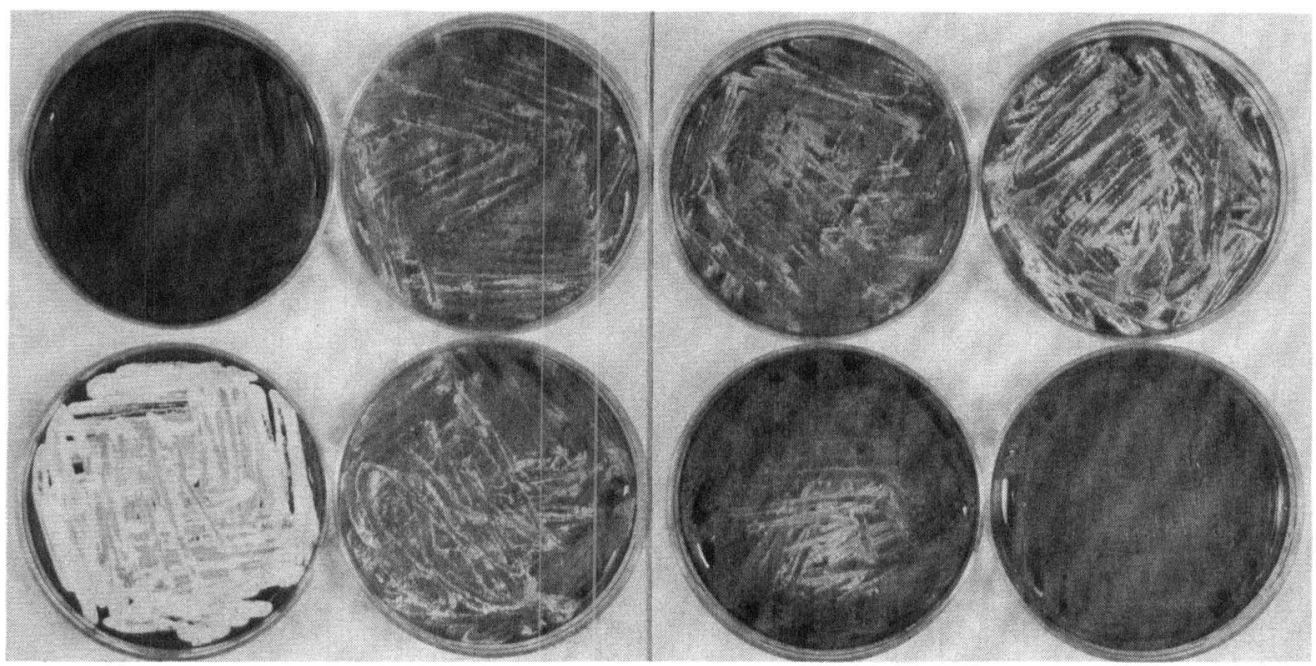

Fig. 2. Development of aerial mycelium of Streptomyces sp. MA406-A-1 on plates at fixed concentrations of decoyinine. Spores were spread on sporulation agar supplemented with $1 \%$ polypeptone and various amounts of decoyinine [left to right: $0,0.005,0.01$ and $0.02 \mathrm{~mm}$ (upper line); $0.05,0 \cdot 1,0.2$ and $0.5 \mathrm{~mm}$ (lower line)]. The plates were incubated at $30^{\circ} \mathrm{C}$ for $3 \mathrm{~d}$.

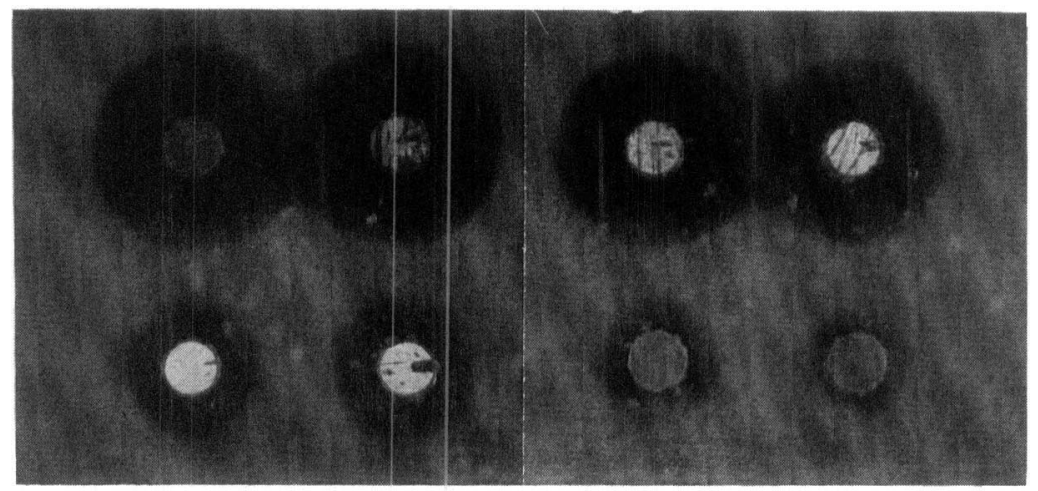

Fig. 3. Qualitative assay of formycin produced after $3 \mathrm{~d}$ incubation in sporulation agar supplemented with $1 \%$ polypeptone and various amounts of decoyinine (see Fig. 2). Agar pieces (diameter $8 \mathrm{~mm}$ ) cut from each of the plates shown in Fig. 2 were put on a formycin assay plate inoculated with Xanthomonas oryzae as the test organism, and incubated at $30^{\circ} \mathrm{C}$ for $30 \mathrm{~h}$. The order of samples is the same as in Fig. 2.

decreased to one-thirc of the initial value from 582 to $198 \mathrm{pmol}\left(\mathrm{mg}\right.$ dry wt) ${ }^{-1}$ ], $30 \mathrm{~min}$ after the addition of decoyinine and it remained lower thai: the initial value for at least $4 \mathrm{~h}$ (Fig. $5 a$ ). GDP decreased in parallel with the decrease in GTY (not shown). GMP could not be measured in this assay system. The other nucleotides assayed (ATP, UTP and CTP) increased slightly (to up to $125 \%$ of the initial value) or were unaffected. The pool size of ppGpp did not change on the addition of decoyinine, remaining at $15-20$ pmol ( $\mathrm{mg}$ dry $\mathrm{wt})^{-1}$ during the $4 \mathrm{~h}$ incubation (not shown). The size of the pppGpp pool was too small to estimate (less than one-fifth that of ppGpp). In complex medium the decrease in GTP was more pronounced, to $16 \%$ of the initial value [from 690 to $109 \mathrm{pmol}(\mathrm{mg} \text { dry wt })^{-1}$ ] after $30 \mathrm{~min}$ (Fig. $5 b$ ). In contrast, ATP, CTP and UTP all showed a transient two-to threefold increase. This marked increase was probably due to a partial inhibition of RNA synthesis resulting from the limited availability of GTP. The 

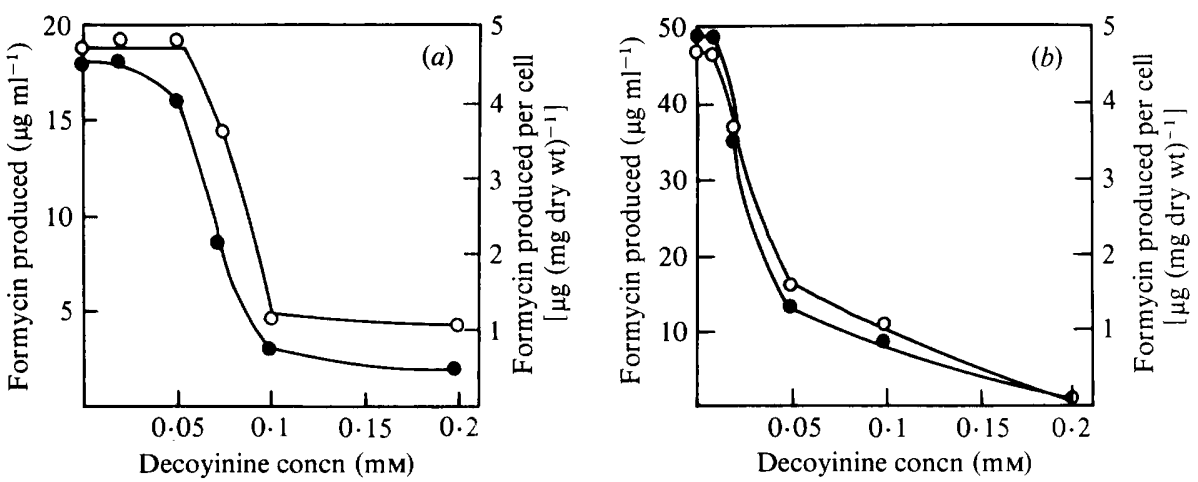

Fig. 4. Effect of decoyinine on formycin production in synthetic medium $(a)$ or in complex (maltose/polypeptone/yeast extract) medium (b). Cells were grown in the appropriate medium for $6 \mathrm{~h}$, transferred to fresh medium of the same composition but containing various amounts of decoyinine, and incubated for $10 \mathrm{~h}(a)$ or $18 \mathrm{~h}(b)$. Formycin produced; $\bigcirc$, formycin produced per mg dry wt of cells.

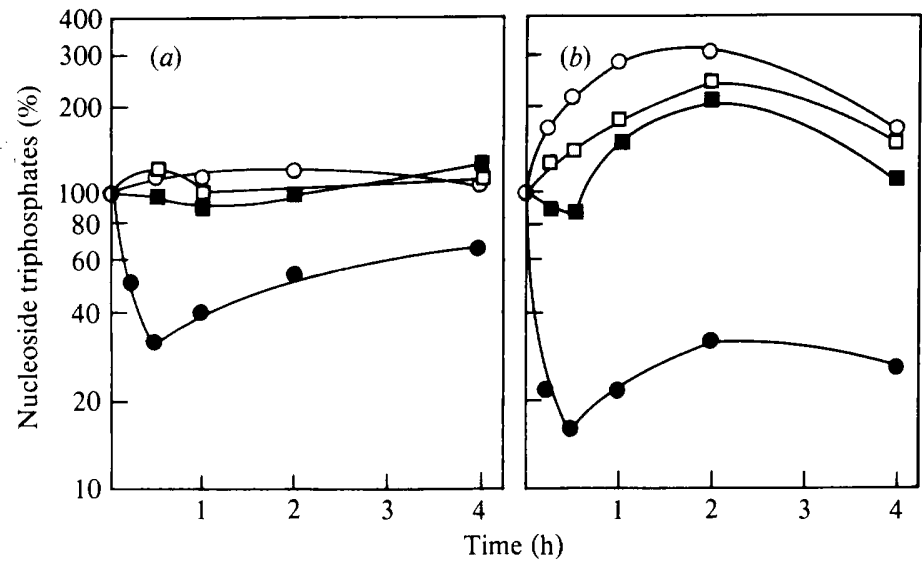

Fig. 5. Changes in the intracellular concentrations of nucleoside triphosphates after the addition of decoyinine. Cells were grown in synthetic medium ( $50 \mathrm{ml}$ per flask) $(a)$ or in maltose/polypeptone/yeast extract medium $(50 \mathrm{ml}$ per flask) $(b)$ for $6 \mathrm{~h}$, then decoyinine was added to each flask to give a final concentration of $0.1 \mathrm{~mm}(a)$ or $0.2 \mathrm{~mm}(b)$, and incubation was continued. At the indicated times, cells in each flask were quickly filtered, and extracted. The nucleotide contents at zero time $[\mathrm{pmol}(\mathrm{mg}$ dry wt $)^{-1}$ ] were : (a) GTP, 582; ATP, 1550; UTP, 513; CTP, 341; and (b) GTP, 690; ATP, 1390; UTP, 465; CTP, 370. - GTP; O, ATP; $\square$, UTP; $\square$, CTP.

concentrations of these three nucleotides eventually decreased again, possibly due to feed-back inhibition of their synthesis. Thus, decoyinine addition resulted in a decrease in the GTP pool in both synthetic and complex medium.

The effect of decoyinine on antibiotic production by Streptomyces strains was further studied using $S$. parvulus ATCC 12434, which produces actinomycin D and whose aerial mycelium formation could be initiated by decoyinine (see above). The amount of actinomycin D produced per mg dry wt of cells decreased (by $80 \%$ with $0.2 \mathrm{~mm}$-decoyinine) when cells growing exponentially ( $15 \mathrm{~h}$ from inoculation) were added to medium containing $0 \cdot 01-2 \mathrm{~mm}$-decoyinine, followed by a further $120 \mathrm{~h}$ incubation (not shown). 


\section{DISCUSSION}

All four Streptomyces strains examined developed aerial mycelium on the addition of decoyinine. This is of interest because sporulation of Bacillus subtilis (an endospore-forming bacterium) has been shown to be triggered by a partial decrease of the GTP pool in the presence of excess carbon, nitrogen and phosphate sources (Lopez et al., 1979; Freese, 1981; Ochi et al., 1981). As in B. subtilis, a decrease in the pool of GTP (or some closely related molecule) may be a sufficient signal for the initiation of aerial mycelium formation of Streptomyces. Addition of decoyinine indeed resulted in a decrease of the intracellular GTP pool of Streptomyces sp. MA406-A-1 (Fig. 5). Therefore, it seems likely that similar physiological signal(s) are involved in initiating differentiation of Bacillus and Streptomyces, though the morphological processes of differentiation of these bacteria are obviously different. It is not known whether the lowered ability of decoyinine to stimulate aerial mycelium formation in the presence of high levels of nitrogen source is due to interference with the initiation process per se, or to interference with the process of development following its initiation.

Regardless of the successful initiation of aerial mycelium formation, addition of decoyinine did not result in an increase of ability to produce formycin or actinomycin $D$. These findings are in agreement with results for $B$. subtilis, in which a decrease in GTP content initiated sporulation but not antibiotic production (Ochi \& Ohsawa, 1984; Ochi, 1985). Therefore, different physiological signals seem to regulate differentiation and secondary metabolism, though the two processes may share (at least partially) some common regulatory elements. The stringent response, which accompanies an increase in the intracellular concentrations of ppGpp and pppGpp, could be a candidate for such a signal to initiate secondary metabolism of Streptomyces, as has been shown in B. subtilis (Ochi \& Ohsawa, 1984). The presence of the stringent response has been well documented by Riesenberg et al. (1984) for Streptomyces hygroscopicus. The ability of Streptomyces sp. MA406-A-1 to produce formycin increased dramatically when the cells underwent a partial stringent response, while a relaxed mutant did not show such an increase (unpublished observations).

The involvement of A-factor (Horinouchi et al., 1983; Gräfe et al., 1984) and the ornithine cycle (especially with respect to citrullire) (Vargha et al., 1983; Ochi et al., 1984) in the differentiation and secondary metabolism of Streptomyces has been reported. The possible role of GTP or ppGpp in regulating the synthesis (or function) of these factors is of interest to uncover the physiological switching and it: transmission to the transcription and/or translation machinery.

The author acknowledges J. E. Grady for the supply of decoyinine, and S. Yashima and Y. Okami for the supply of Streptomyces sp. MA406-A-1. Thanks are alsc expressed to E. Freese and M. Okanishi for their valuable discussions, and to $\mathrm{H}$. Aoki and $\mathrm{M}$. Kohsaka for encouragement to proceed with this study.

\section{REFERENCES}

Chater, K. F. (1984). Morphological and physiological differentiation in Streptomyces. In Microbial Development, pp. 89-116. Edited by R. Losick \& L. Shapiro. Cold Spring Harbor, New York: Cold Spring Harbor Laboratory.

Chater, K. F. \& Hopwood, D. A. (1984). Streptomyces genetics. In The biology of the Actinomycites, pp. 229286 . Edited by M. Goodfellow, M. Mordarski \& S. T. Williams. London: Academic Press.

FREESE, E. (1981). Initiation of bacterial sporulation. In Sporulation and Germination-Proceedings of the VIII International Spores Conference, pp. I 12. Edited by H. S. Levinson, A. L. Sonenshein \& D. J. Tipper. Washington, DC: American Society for Microbiology.

Freese, E. B., Olempska-Beer, Z., Hartig, A \& FrEESE, E. (1984). Initiation of meiosis and spor sla- tion of Saccharomyces ceretisiae by sulfur or guanine deprivation. Derelopmental Biology 102, 438451.

Gräfe, U., Reinhardt, G., Krebs, D., Fritt, I. \& Fleck, W. F. (1984). Pleiotropic effects of a butyrolactone-type autoregulator on mutants of Streptomyces griseus blocked in cytodifferentiation. Journal of General Microbiology 130. 12371245.

Horinouchi, S., Hara, O. \& Beppu, T. (1983). Cloning of a pleiotropic gene that positively controls biosynthesis of A-factor, actinorhodin, and prodigiosin in Streptomyces coelicolor A3(2) and Streptomyces liridans. Journal of Bacteriology 155, 1238-1248.

Kalakoutskil, L. V. \& Agre, N. S. (1976). Comparative aspects of development and differentiation in actinomycetes. Bacteriological Reriens 40, 469524.

KaTZ, E. \& WeISSBaCH, H. (1963). Incorporation of ${ }^{1+} \mathrm{C}$ labeled amino acids into actinomycin and 
protein by Streptomyces antibioticus. Journal of Biological Chemistry 238, 666-675.

Lopez, J. M., Marks, C. L. \& Freese, E. (1979). The decrease of guanine nucleotides initiates sporulation of Bacillus subtilis. Biochimica et biophysica acta $\mathbf{5 8 7}$, 238-252.

OCHI, K. (1985). Sporulation and antibiotic production by Bacillus subtilis mutants deficient in intracellular proteases. Agricultural and Biological Chemistry 49, 905-907.

OChI, K. \& Freese, E. (1983). Effect of antibiotics on sporulation caused by the stringent response in Bacillus subtilis. Journal of General Microbiology 129, 3709-3720.

OCHI, K. \& OHSAWA, S. (1984). Initiation of antibiotic production by the stringent response of Bacillus subtilis Marburg. Journal of General Microbiology 130, 2473-2482.

Ochi, K., Iwamoto, S., Hayase, E., Yashima S. \& OKAMI, Y. (1974). Biosynthesis of formycin: role of certain amino acids in formycin biosynthesis. Journal of Antibiotics 27, 909-916.

OChI, K., Yashima, S., Eguchi, Y. \& Matsushita, K. (1979). Biosynthesis of formycin: incorporation and distribution of ${ }^{13} \mathrm{C}-,{ }^{14} \mathrm{C}-$, and ${ }^{15} \mathrm{~N}$-labeled compounds into formycin. Journal of Biological Chemistry 254, 8819-8824.

OChI, K., Kandala, J. C. \& Freese, E. (1981). Initiation of Bacillus subtilis sporulation by the stringent response to partial amino acid deprivation. Journal of Biological Chemistry 256, 6866-6875.

Ochi, K., Saito, Y., Umehara, K., Ueda, I. \& KOHSAKA, M. (1984). Restoration of aerial mycelium and antibiotic production in a Streptomyces griseoflavus arginine auxotroph. Journal of General Microbiology 130, 2007-2013.

Redshaw, P. A., McCann, P. A., Sankaran, L. \& Pogell, B. M. (1976). Control of differentiation in streptomycetes: involvement of extrachromosomal deoxyribonucleic acid and glucose repression in aerial mycelia development. Journal of Bacteriology 125, 698-705.

Riesenberg, D., Bergter, F. \& Kari, C. (1984). Effect of serine hydroxamate and methyl $\alpha$-Dglucopyranoside treatment on nucleoside polyphosphate pools, RNA and protein accumulation in Streptomyces hygroscopicus. Journal of General Microbiology 130, 2549-2558.

Vargha, G., Karsai, T. \& Szabo, G. (1983). A conditional aerial mycelium-negative mutant of Streptomyces fradiae with deficient ornithine carbamoyltransferase activity. Journal of General Microbiology 129, 539-542.

Williams, W. K.\& Katz, E. (1977). Development of a chemically defined medium for the synthesis of actinomycin D by Streptomyces pariulus. Antimicrobial Agents and Chemotherapy 11, 281-290. 